Journal of Aquaculture Feed Science and Nutrition 7 (1-3): 1-5, 2015

ISSN: $2070-1667$

(C) Medwell Journals, 2015

\title{
Effect of Terminalia catappa on Growth and Heamatology of Clarias gariepinus Juveniles
}

\author{
Olapade Olufemi Julius and Kargbo Mariatu \\ Department of Aquaculture and Fisheries Management, \\ School of Natural Resources Management, Njala University, \\ Njala Campus, Sierra Leone, Africa
}

\begin{abstract}
The growth and haematological responses of the African catfish (Clarias gariepinus Burchell1822) to graded levels of Terminalia catappa (African almond) seed meal (TSM) was investigated. Five isonitrogenous and isoenergetic diets (40\% crude protein) containing 0, 25, 50, 75 and 100\% TSM were formulated. Clarias gariepinus juveniles $(30.7 \pm 0.75)$ stocked at $10 \mathrm{fish} / 50 \mathrm{~L}$ plastic troughs were fedtwice daily for 112 days. Temperature, $\mathrm{pH}$ and dissolved oxygen were the determined water quality variables. Data obtained were analyzed using Analysis of Variance (ANOVA), correlation and LSD and was separated at 5\% probability level. The highest Mean Weight Gain (MWG) was at 50 and $0 \%$ and did not follow a specific order of increase. Specific Growth Rate (SGR), Protein Efficiency Ratio (PER), Protein Intake (PI) were significantly higher ( $\mathrm{p}<0.05$ ) at 0 and $50 \%$ TSM inclusion. Percentage Survival Rate $(\% \mathrm{SR})$ was unrelated to the treatment diets. There were slight differences in the values of haematological parameters of the C. gariepinus at the different inclusions of TSM. Physicochemical variables in the experiment were within levels recommended for the culture of fresh water fish.
\end{abstract}

Key words: Terminalia seed meal, haematology, Clarias gariepinus, PER, PI

\section{INTRODUCTION}

Protein requirements are fundamental in fish diet and as such the requirement need to be met in the right quality and quantity in order to obtain the desired growth in cultured fish species. High quality protein according to Fagbenro and Adeparusi (2003) can be used to maintain an active metabolism in fish. Fish protein is among the most quality sources of animal protein but are often the major contributor to the high fish feed cost and as such there is the need to search for alternative protein sources to replace fishmeal in fish feed. Several studies have been carried out using protein of plant origin in fish diet (Alegbeleye et al., 2001; Keembiychetty and de Silva, 1993; Osuigwe et al., 2005; Sotolu, 2008; Sotolu and Faturoti 2008). According to Regost et al. (1999) and Fournier et al. (2004), a mixture of plant protein sources is however more appropriate than the incorporation of a single plant source because of improved amino acids profile. Interest in the utilization of Terminalia catappa as source of raw materials for feed ration formulation is growing among nutritionists especially because of its very high protein content $(19-22 \%)$ and oil (50-52\%). T. catappa is a large, deciduous tree with smooth grey bark and whorled branches that form a canopy and is found in tropical and subtropical regions. The timber is moderately easy to saw and work, polishes well has wide applications and is classed as a good constructional timber (Inbaraj and Sulochana, 2006). The fruit is large (2-3 inches), edible, fleshy, green (unripe) and yellow or red (when ripe). The fruit has a husk $(34.08 \%)$, a porous and fibrous pericarp $(8.97 \%)$ and an exocarp which is relatively thin and smooth while the hard endocarp $(46.63 \%)$ enclosed an edible kernel (10.32\%) (Untwal and Kondawar, 2006; Inbaraj and Sulochana, 2006; Muhammad and Oloyede, 2004). The leaves of $T$. catappa have been reported to have medicinal values (Lin et al., 1999; Chen et al., 2000). The fruit is edible, fleshy, green (unripe) and yellow or red (when ripe). The exocarp is relatively thin and smooth and the endocarp is hard. When cracked, a kernel is obtained and this can be consumed as well. The kernel of T. catappa according to Ratnasooriya and Dharmasiri (2000) has aphrodisiac activity and may be useful in the treatment of certain form of sexual inadequacies especially premature ejaculation.

This present study investigates the growth and haematological responses of the African catfish (C. gariepinus Burchell 1882) juveniles to Terminalia catappa Seed Meal (TSM) used as a partial

Corresponding Author: Olapade Olufemi Julius, Department of Aquaculture and Fisheries Management, School of Natural Resources Management, Njala University, Njala Campus, Sierra Leone, Africa 
substitute for fish meal in compounded fish diet. The effect of the formulated diet on physico-chemical parameters of the culture environment was also investigated.

\section{MATERIALS AND METHODS}

Collection and processing of Terminalia catappa: Large collection of specimen of T. catappa (African almond) was obtained towards the end of the rainy season within Njala University Campus. Samples were first sun-dried for a period of 1 month and thereafter the shell (endocarp) was crushed using hammer and stone to remove the fleshy seeds. The dried seeds were roasted in a hot pan filled with clean river sand. The roasted seeds of T. catappa were further dried before finally grinding preparatory to apportioning and blending.

Collection and preparation of feedstuff: The ingredients used along with $T$. catappa in this study include fishmeal (FM 62\% CP), yellow maize, soya beans, vitamin premix (methionine) and starch as binder. The feedstuffs were bought at a nearby market. The soya bean was pre-processed by roasting before utilization to rid it of growth inhibitors. All ingredients were finely grinded, blended with vitamin premix and starch and thereafter extruded using a meat mincer. Clarias gariepinus juveniles used for this study were obtained from River Tia (Njala axis of Moyamba district). The fish samples were acclimated in a plastic trough for 3 days. After acclimation ten juveniles of $C$. gariepinus mean weight $30.7 \pm 0.75$ were randomly selected and distributed into the five treatments. The fish weight was determined with the aid of Soehnle Electronic Kitchen Balance (Model Art-Nr. 65055). Each treatment consists of three replicates of $50 \mathrm{~L}$ capacity plastic trough and the set-up was a completely flow-through set-up. A constant inflow and out flow of $2.5 \mathrm{~L}$ water volume/minute was maintained throughout the study. Each of the treatment was assigned to one of the experimental diets containing different levels of T. catappa seed meal $0 \%$ (control), 25, 50, 75 and $100 \%$, respectively. Fish were fed twice daily (morning and evening) for 124 days between 9.00-09.30 h and $19.00-19.30 \mathrm{~h}$ at $5 \%$ body weight with the daily ration divided into two. Clearing of faecal materials, cleaning of troughs and changing of water were done every 3 days while fish sampling was done bi-weekly. Mean weight changes were determined with Soehenle Kitchen Electronic Balance (Model Art-Nr 65055). Fish mortality was recorded daily and is accounted for in adjustment of feeding and mean weight measure. Water quality variables determined for this study were temperature $\left(\mathrm{T}^{\circ} \mathrm{C}\right)$,
Dissolved Oxygen (DO) and $\mathrm{pH}$ and were determined bi-weekly using Pometer pH-009 (III) Pen type meter, Hanna portable instrument model H198204 No. 227075. Dissolved oxygen was determined after Boyd (1979) titrimetrically and was proved with Jenwey $970 \mathrm{DO}_{2} \mathrm{~m}$ (No. 970-201).

Feed utilization: Data were collected weekly on fish growth performance and nutrient utilization by determining Mean Weight Gain (MWG), Feed Intake (FI), Specific Growth Rate (SGR), Percentage Survival Rate (\% SR), Protein Efficiency Ratio (PER), Feed Conversion Ratio (FCR) and Protein Intake (PI) using recommended procedures.

Haematological study: After 124 days haematological studies was carried out on the fish samples. Fish haematology was carried out using standard procedures (Svobodova et al., 1991; Wagner et al., 1997). Initial blood samples were collected prior to feeding trial that is 0th day while the final blood samples were collected from the fish in triplicates on the last day of the experiment (124th day). The fishes were taken out individually using a small hand net and placed belly upward on a table. Blood samples of about $4 \mathrm{~mm}$ were collected from the caudal peduncle with the aid of a $2 \mathrm{~cm}^{3}$ plastic hypodermic syringe. The blood sample was dispensed into Ethylene Di-Amine Tetra Acetic Acid (EDTA) an anti-coagulant placed in a plastic sample bottles. The use of plastic syringe is a necessary precaution with fish blood because contact with glass result in decreased coagulation time. The haematological indices of Mean Cell Haemoglobin Concentration $(\mathrm{MCHC})$, Mean Cell Volume (MCV), Mean Cell Haemoglobin $(\mathrm{MCH})$ were calculated using the total Red Blood Cell count (RBC), Haemoglobin concentration (Hb) and Haematocrit (HCT).

Statistical analysis: Data collected were subjected to Analysis of Variance (ANOVA) and correlation analysis using the SPSS package Version 10 and significant mean differences were separated at $5 \%$ probability level using Duncan multiple range test.

\section{RESULTS AND DISCUSSION}

Diet ingredients, proximate composition and mineral contents of formulated feed used for the experiment are presented in Table 1. Chemical components determined for the diets include crude protein, crude fat, crude fiber, ash and dry matter while the mineral contents of the diets are $\mathrm{Na}, \mathrm{K}, \mathrm{Ca}, \mathrm{P}, \mathrm{Mg}$ (determined as \%), $\mathrm{Fe}, \mathrm{Zn}$ and $\mathrm{Cu}$ (determined as $\mathrm{mg} / \mathrm{kg}$ ). The proximate analysis of 
Table 1: Diet formulation, proximate composition and mineral contents of

\begin{tabular}{|c|c|c|c|c|c|}
\hline Diet composition & $\begin{array}{c}\text { Diet } 1 \\
(0 \%)\end{array}$ & $\begin{array}{l}\text { Diet } 2 \\
(25 \%)\end{array}$ & $\begin{array}{l}\text { Diet } 3 \\
(50 \%)\end{array}$ & $\begin{array}{l}\text { Diet } 4 \\
(75 \%)\end{array}$ & $\begin{array}{r}\text { Diet } 5 \\
(100 \%)\end{array}$ \\
\hline Fish meal & 14.70 & 11.10 & 7.35 & 3.65 & 0.00 \\
\hline T. cotoppa meal & 0.00 & 3.65 & 7.35 & 11.10 & 14.70 \\
\hline Yellow maize & 30.00 & 30.00 & 30.00 & 30.00 & 30.00 \\
\hline Soybean meal & 54.80 & 54.80 & 54.80 & 54.80 & 54.80 \\
\hline Vitamin & 0.25 & 0.25 & 0.25 & 0.25 & 0.25 \\
\hline Salt & 0.25 & 0.25 & 0.25 & 0.25 & 0.25 \\
\hline \multicolumn{6}{|c|}{ Chemical composition (\%) on a dry matter basis } \\
\hline Crude protein & 40.68 & 38.55 & 39.01 & 39.01 & 39.79 \\
\hline Crude fat & 5.26 & 4.9 & 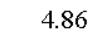 & 4.79 & 4.83 \\
\hline Crude fibre & 4.37 & 4.89 & 4.9 & 5.12 & 5.39 \\
\hline Ash & 15.47 & 14.69 & 14.78 & 14.88 & 14.97 \\
\hline Dry matter & 91.76 & 90.72 & 90.78 & 90.86 & 91.23 \\
\hline \multicolumn{6}{|c|}{ Mineral content ( $\%$ and $\mathrm{mg} / \mathrm{kg}$ ) } \\
\hline $\mathrm{T}(\%)$ & 0.57 & 0.64 & 0.73 & 0.79 & 0.88 \\
\hline$(\%)$ & 1.37 & 1.41 & 1.51 & 1.68 & 1.79 \\
\hline $\mathrm{Ca}(\%)$ & 1.18 & 1.23 & 1.28 & 1.35 & 1.41 \\
\hline & 1.87 & 1.97 & 2.04 & 2.16 & 2.27 \\
\hline $\mathrm{Mg}$ & 0.42 & 0.61 & 0.74 & 0.83 & 0.96 \\
\hline $\left.\mathrm{kg}^{-1}\right)$ & 314.20 & 296.20 & 318.70 & 326.50 & 343.70 \\
\hline $\mathrm{Zn}\left(\mathrm{mg} \mathrm{kg}^{-1}\right)$ & 41.20 & 36.80 & 44.30 & 46.80 & 49.20 \\
\hline $\mathrm{Cu}\left(\mathrm{mg} \mathrm{kg}^{-1}\right)$ & 7.80 & 1.30 & 15.40 & 16.70 & 17.30 \\
\hline
\end{tabular}

Table 2: Proximate composition of processed unmixed TSM

\begin{tabular}{lc}
\hline Parameters determined (\%) & Percentage composition (\%) \\
\hline Crude protein & 24.50 \\
Crude fat & 28.00 \\
Ether extract & 36.00 \\
Ash & 6.00 \\
Dry matter & 2.34 \\
\hline
\end{tabular}

Table 3: Growth and nutrient utilization of experimental fish fed varying inclusion of TSM diets and mean water quality parameters Percentage inclusion level of TSM seed meal

\begin{tabular}{|c|c|c|c|c|c|}
\hline \multirow[b]{2}{*}{ Parameters } & \multicolumn{5}{|c|}{ Percentage inclusion level of TSM seed meal } \\
\hline & $0 \%$ & $25 \%$ & $50 \%$ & $75 \%$ & $100 \%$ \\
\hline Culture period (days) & 112.00 & 112.00 & 112.00 & 112.00 & 112.00 \\
\hline Initial mean weight (g) & 30.00 & 30.50 & 31.20 & 31.70 & 30.00 \\
\hline Final mean weight (g) & 58.30 & 42.10 & 61.70 & 51.90 & 36.20 \\
\hline MWG (g) & 28.30 & 11.60 & 30.50 & 20.20 & 6.20 \\
\hline FI (g)/Fish & 36.40 & 30.50 & 36.40 & 30.50 & 27.50 \\
\hline SGR & 0.26 & 0.13 & 0.26 & 0.19 & 0.07 \\
\hline PER & 1.94 & 0.95 & 2.09 & 1.66 & 0.56 \\
\hline FCR & 1.27 & 2.63 & 1.19 & 1.51 & 4.44 \\
\hline PI & 14.56 & 12.20 & 14.56 & 12.20 & 11.00 \\
\hline rate (\%) & 70.00 & 67.00 & 60.00 & 87.00 & 73.00 \\
\hline $\mathrm{pH}$ & 7.50 & 7.60 & 7.70 & 7.70 & 7.30 \\
\hline Temperature $\left({ }^{\circ} \mathrm{C}\right)$ & 29.00 & 27.00 & 29.00 & 28.00 & 27.00 \\
\hline Oxygen $\left(\mathrm{mg} \mathrm{L}^{-1}\right)$ & 5.00 & 5.00 & 5.10 & 5.00 & 5.10 \\
\hline
\end{tabular}

Terminalia catappa Seed Meal (TSM) is presented in Table 2. Growth and nutrient parameters of the fish fed with graded Terminalia catappa seed meal diets and mean water quality parameters of the study are shown in Table 3. The results of the feeding trials showed that the experimental fish responded to all the diets irrespective of their composition. The fish effectively utilized the T. catappa seed meal diet for growth.

Growth and nutrients utilization was higher at 50 and $75 \%$ inclusion of TSM, respectively and this compared favourably with the control diet ( $0 \% \mathrm{TSM})$. According to
Muhammad and Oloyede (2004), the seed of T. catappa is very rich in protein (19-22\%) and oil (50-52\%). Terminalia catappa has been found to have multi use properties. The leaf, bark and fruits are used in treating dysentery, rheumatism, cough and asthma. The fruit is also helpful in the treatment of leprosy and headaches and the leaves are specifically used in getting rid of intestinal parasites, treatment of eye problems, wounds and liver problems (Kritikar and Basu, 1991; Corner, 1997; Anonymous, 1976). According to Nagappa et al. (2003) and Moody et al. (2003), the fruit and the leaves have been scientifically proven to have anti-diabeticand anti sickling properties. The chloroform and methanol extracts of the bark and root displayed strong antimicrobial activities (Pawar and Pal, 2002). The amino acid and mineral profile of this seed has equally been documented (Osagie, 1998). Feed intake which is a determinant of fish performance did not decrease consistently with the T. catappa seed meal inclusion as recorded by several researchers in experiment using other plant protein materials. The order of feed intake was $0 \%$ and $50>25 \%$ and $75>100 \%$.

The importance of feed intake by fish as a determinant of fish performance has been strongly emphasized (Preston and Leng, 1987; Faturoti, 1989; Pillay, 1990). Anderson et al. (1984) and Keembiychetty and de Silva (1993) pointed out the possibility of protein sparing effects by other nutrients in a feed that is as more energy was supplied for metabolism through other nutrients, more protein is available for fish growth and tissue development. All diets used in the trial produced higher values of fish carcass protein and lipid than initial values however with marginal differences among the treatments indicating different utilization of the diets. The relatively high values of crude protein could be viewed alongside the research by Alegbeleye et al. (2001) who reported that effective utilization of Bambara groundnut at varying inclusion was responsible for variation in Heteroclarias carcass protein and lipid. Crude fiber was not found in the fish carcass composition and this has been associated with effective utilization of experimental diets (Sotolu, 2008). The physico-chemical variables determined for the study were within the values recommended for the culture of fresh water species (Omitoyin, 2007).

Carcass and haematological composition of experimental fish fed TSM are shown in Table 4. Haematological parameters determined include $\mathrm{PVC}, \mathrm{Hb}$, RBC, WBC, MCV, MCHC, Lym and Neut. The result of the study showed a slight decrease in the values of haematological parameters of the experimental fish at the different level of TSM inclusion. Haemoglobin and Parked Cell Volume (PCV) have been suggested as tests that is 
J. Aquacult. Feed Sci. Nutr., 7 (1-3): 1-5, 2015

Table 4: Carcass and haematological composition of experimental fish fed TSM diet for 112 days

\begin{tabular}{|c|c|c|c|c|c|c|}
\hline \multirow[b]{2}{*}{ Parameters (\%) } & \multirow{2}{*}{$\begin{array}{l}\text { Initial } \\
\text { values of fish }\end{array}$} & \multicolumn{5}{|c|}{ Final values at different TSM inclusion rates } \\
\hline & & $0 \%$ & $25 \%$ & $50 \%$ & $75 \%$ & $100 \%$ \\
\hline Crude protein & 51.68 & 52.7 & 52.6 & 53.8 & 52.2 & 51 \\
\hline Crude fat & 4.67 & 1 & 1 & 1 & 2 & 1 \\
\hline Ether extract & 1.06 & 23 & 22.3 & 25.7 & 23 & 27.7 \\
\hline Ash & 13.76 & 17.3 & 18 & 14 & 18 & 14.7 \\
\hline Dry matter & 92.81 & 2.22 & 2.28 & 2.22 & 2.22 & 2.22 \\
\hline \multicolumn{7}{|l|}{ Haematocrit } \\
\hline PVC (\%) & 8 & $6.3 \pm 2.52$ & $9.3 \pm 2.09$ & $7.3 \pm 4.04$ & $5.3 \pm 2.52$ & $6.3 \pm 2.09$ \\
\hline $\mathrm{Hb}(\mathrm{g} / 100 \mathrm{~mL})$ & 2.7 & $2.0 \pm 0.73$ & $3.0 \pm 0.82$ & $2.4 \pm 1.42$ & $1.7 \pm 0.91$ & $2.0 \pm 0.75$ \\
\hline $\mathrm{RBC}\left(\times 10^{6} / \mathrm{mL}\right)$ & 2.02 & $0.75 \pm 0.48$ & $0.94 \pm 0.78$ & $0.94 \pm 0.80$ & $1.17 \pm 0.78$ & $1.43 \pm 0.86$ \\
\hline $\mathrm{WBC}\left(\times 10^{3} / \mathrm{mL}\right)$ & 0.8 & $3.6 \pm 2.36$ & $3.6 \pm 2.62$ & $2.4 \pm 1.78$ & $3.3 \pm 2.32$ & $2.4 \pm 1.61$ \\
\hline MCV (fl) & 39 & $33 \pm 4.36$ & $81.3 \pm 35.23$ & $100.0 \pm 40.58$ & $65.3 \pm 46.31$ & $71.0 \pm 70.66$ \\
\hline $\mathrm{MCH}(\mathrm{pg})$ & 13 & $44.7 \pm 44.41$ & $26.0 \pm 12.77$ & $31.3 \pm 11.01$ & $21.7 \pm 15.96$ & $21.3 \pm 15.82$ \\
\hline MCHC (\%) & 3 & $3.0 \pm 0.00$ & $3.0 \pm 0.00$ & $3.0 \pm 0.00$ & $3.0 \pm 0.00$ & $3.0 \pm 0.00$ \\
\hline Lym (\%) & 40 & $26.0 \pm 5.29$ & $25.3 \pm 4.51$ & $26.0 \pm 6.00$ & $27.0 \pm 6.24$ & $27.0 \pm 7.00$ \\
\hline Neut $(\%)$ & 59 & $73.0 \pm 4.58$ & $73.7 \pm 5.13$ & $72.3 \pm 5.03$ & $71.7 \pm 5.86$ & $72.3 \pm 6.50$ \\
\hline
\end{tabular}

can be carried out on routine basis in fish hatchery as a check on fish health status (Klinger et al., 1996). Haematological characteristics have been widely used in clinical diagnosis of diseases and pathologies of human and domestic animals. The applications of haematological techniques have proved valuable for fishery biologist in assessing the health of the fish (Fagbenro and Adeparusi, 2003) and monitoring stress response (Soivio and Oikari, 1976). Some of the haematologicalparameters measured in this study were slightly low and this could be associated the condition under which the fish were kept. In a stress situation, erythrocyte count has been known to be the first parameter to be affected. Increase in WBC (leucopomia) as observed in the fish fed T. catappa seed meal diet is attributed to increase in the production of leucocytes in the haematopoietic tissue of the kidney and perhaps the spleen. According to Wedmemayer and Wood (1974), the primary consequences of observed changes in leucocyte count in stressed fish are the expression of the immune system and increased susceptibility to disease.

\section{CONCLUSION}

In conclusion, C. gariepinus performed better at $50 \%$ TSM inclusion and as such it is recommended as the best level of inclusion.

\section{REFERENCES}

Alegbeleye, W.O., A.O. Oresegun and O. Omitoyin, 2001. Use of bambara groundnut (Vigna subterranean) meal in the diets of Heteroclarias fingerlings. Moor J. Agric. Res., 2: 54-59.

Anderson, J., A.J. Jackson, A.J. Matty and B.S. Capper, 1984. Effects of dietary carbohydrate and fibre on the tilapia Oreochromis niloticus (L.). Aquaculture, 37: 303-314.
Anonymous, 1976. The Wealth of India Raw Materials. Vol. III. National Institute of Science Communication, CSIR, New Delhi, India.

Chen, P.S., J.H. Li, T.Y. Liu and T.C. Lin, 2000. Folk medicine Terminalia catappa and its major tannin component, punicalagin, are effective against beomycin-induced genotoxicity in Chinese hamster ovary cells. Cancer Lett., 152: 115-122.

Corner, E.J.H., 1997. Wayside Trees of Malaya. 4th Edn., Vol. II, Malayan Nature Society, Kuala Lumpur, pp: 251-252.

Fagbenro, A.O. and E. Adeparusi, 2003. Feedstuff and dietary substitution for farmed fish in Nigeria. Proceedings of the Pan African Fish and Fisheries Conference Contonou, November 10-14, 2003, Benin, pp: 276.

Faturoti, E.O., 1989. Effects of supplementary feeding and organic manuring on the production of African catfish: Clarias gariepinus (Burchell, 1822). J. West Afr., Fish, 4: 187-195.

Fournier, V., C. Huelvan and E. Desbruyeres, 2004. Incorporation of a mixture of plant feedstuffs as substitute for fish meal in diets of juvenile turbot (Psetta maxima). Aquaculture, 236: 451-465.

Inbaraj, B.S. and N. Sulochana, 2006. Mercury adsorption on a carbon sorbent derived from fruit shell of Terminalia catappa. J. Hazard. Mater., 133: 283-290.

Keembiychetty, C.N. and S.S. de Silva, 1993. Performance of juvenile Oreochromis niloticus (L.) reared on diets containing cowpea, Vigna catiang and black grain, Phaseolus mungo seeds. Aquaculture, 112: 207-215.

Klinger, R.C., V.S. Blazer and C. Echevarria, 1996. Effects of dietary lipid on the hematology of channel catfish, Ictalurus punctatus. Aquaculture, 147: 225-233.

Kritikar, K.R. and B.A. Basu, 1991. Indian Medicinal Plants. 2nd Edn., Periodical Experts Book Agency, New Delhi, India, pp: 856-860. 
Lin, C.C., Y.F. Hsu and T.C. Lin, 1999. Effects of punicalagin and punicalin on carrageenan-induced inflammation in rats. Am. J. Chin. Med., 27: 371-376.

Moody, J.O., F.T. Segun, O. Aderounmu and O.O. Omotade, 2003. Antisickling activity of terminalia catapper leaves harvested at different stages of growth. Nig. J. Nat. Prod. Med., 7: 30-32.

Muhammad, N.O. and O.B. Oloyede, 2004. Assessment of biological value of Terminalia catappa seed meal-based diet in rats. Biokemistri, 16: $49-55$.

Nagappa, A.N., P.A. Thakurdesai, N.V. Rao and J. Singh, 2003. Antidiabetic activity of Terminalia catappa Linn fruits. J. Ethnopharmacol., 88: 45-50.

Omitoyin, O.B., 2007. Introduction to Fish Farming in Nigeria. Ibadan University Press, Nigeria, ISBN-13: 9789781214271, Pages: 90.

Osagie, A.U., 1998. Antinutritional Factors. In: Nutritional Quality of Plant Foods, Osagie, A.U. and O.U. Eka (Eds.). Post Harvest Research Unit, University of Benin, Benin, Nigeria, pp: 120-133.

Osuigwe, D.I., A.I. Obiekezie and G.C. Onuoha, 2005. Some haematological changes in hybrid catfish (Heterobranchus longifilis $\mathrm{x}$ Clarias gariepinus) fed different dietary levels of raw and boiled jackbean (Canavalia ensiformis) seed meal. Afr. J. Biotechnol., 4: 1017-1021.

Pawar, S.P. and S.C. Pal, 2002. Antimicrobial activity of extracts of Terminalia catappa root. Indian J. Med. Sci., 56: 276-278.

Pillay, T.V.R., 1990. Aquaculture Principles and Practices. Fishing News Book Ltd., London UK., pp: 575.

Preston, T.R. and R.A. Leng, 1987. Matching Ruminant Production Systems with Available Resources in the Tropics and Sub-Tropics. Penambul Books, Armidale, Australia, ISBN-13: 9780958829014, Pages: 245.
Ratnasooriya, W.D. and M.G. Dharmasiri, 2000. Effect of Terminalia catappa seeds on sexual behavior and fertility of male rats. Asian J. Androl., 2: 213-219.

Regost, C., J. Arzel and S.J. Kaushik, 1999. Partial or total replacement of fish meal by corn gluten meal in diet for turbot, Psetta maxima. Aquaculture, 180: 99-117.

Soivio, A. and A. Oikari, 1976. Haematological effects of stress on a teleost, Esox lucius L. J. Fish Biol., 8: 397-411.

Sotolu, A.O. and E.O. Faturoti, 2008. Digestibility and nutritional values of differently processed Leucaena leucocephala (Lam. de Wit) seed meals in the diet of African catfish (Clarias gariepinus). Middle-East J. Sci. Res., 3: 190-199.

Sotolu, A.O., 2008. Nutrient potentials of water hyacinth as a feed supplement in sustainable aquaculture. Obeche, 26: 45-51.

Svobodova, Z., D. Pravda and J. Palackova, 1991. Unified Methods of Haematological Examination of Fish. Research Institute of Fish Culture and Hydrobiology, Vodnany, Czechoslovakia, Pages: 31.

Untwal, L.S. and M.S. Kondawar, 2006. Use of Terminalia catappa fruit extract as an indicator in acid-base titrations. Indian J. Pharm. Sci., 68: 399-401.

Wagner, E.J., T. Jeppsen, R. Arndt, M.D. Routledge and Q. Bradwisch, 1997. Effects of rearing density upon cutthroat trout hematology, hatchery performance, fin erosion and general health and condition. Progressive Fish-Culturist, 59: 173-187.

Wedmemayer, G.A. and J.W. Wood, 1974. Stress as a predisposing factor in fish diseases. Fish Leafl. 38. US. Fish Wildlife Services. 